\title{
PROFESIONALISME DAN ETIKA PROFESI SEBAGAI DASAR PERTIMBANGAN TINGKAT MATERIALITAS AKUNTAN PUBLIK
}

\author{
Nurasik $^{1)}$, Santi Rahma Dewi ${ }^{2)}$ \\ Universitas Muhammadiyah Sidoarjo \\ nurasik60@yahoo.com \\ santirahma.d@gmail.com
}

\begin{abstract}
This study aims to find out how the influence of auditor professionalism and professional ethics can help auditors making decisions about the level of materiality, so that it is expected to improve the quality of the auditor's performance making decisions regarding the fairness of a financial report presented by the client, so that the level of public trust in services given by the auditor will increase. This study used quantitative methods. Researcher will select the respondent then spread the questionnaire in order to get the data needed so that the goal can be achieved. This questionnaire was distributed to auditors who work in public accountants in the city of Surabaya. Questionnaires that have been collected are tabulated and obtained using SPSS. It is expected that this research can provide an understanding to auditors to constantly improve their competence adequately and uphold professional ethics in accordance with the existing professional code of ethics, because professionalism is a very important determinant and gives consideration to materiality achieve audit tests that are received independently and objectively for the benefit of its stakeholders. The results of this study will also provide knowledge and understanding to the public or business people to be more selective in choosing the auditor to examine their financial statements.
\end{abstract}

Keywords: Professionalism, Professional Ethics, Materiality, Auditors.

ABSTRAK
Penelitian ini dilakukan untuk mengetahui bagaimana pengaruh profesionalisme auditor dan etika profesi yang dapat membantu auditor dalam pengambilan keputusan penetapan tingkat materialitas sehingga diharapkan akan dapat meningkatkan kualitas kinerja auditor didalam membuat keputusan mengenai kewajaran suatu laporan keuangan yang disajikan oleh klien, sehingga tingkat kepercayaan dari masyarakat terhadap jasa yang diberikan oleh auditor akan semakin meningkat. Penelitian ini menggunakan metode kuantitatif. Didalam pelaksanaan penelitian ini, peneliti akan memilih responden kemudian menyebarkan kuisioner dalam rangka mendapatkan data yang dibutuhkan sehingga bisa tercapai tujuannya. Kuisioner penelitian ini disebar kepada auditor yang berkerja pada akuntan publik yang ada di kota Surabaya. Kuisioner yang telah terkumpul dilakukan tabulasi dan dioleh menggunakan SPSS.Diharapkan dari penelitian ini dapat memberikan pemahaman kepada para auditor agar senantiasa meningkatkan kompetensinya secara memadai dan menegakkan etika profesi sesuai dengan kode etik profesi yang ada, karena profesionalismeauditor yang sangat menentukan dan memberikan pertimbangan terhadap materialitas untuk mencapai tujian audit yang diterima secara independen dan obyektif untuk kepentingan stakeholdernya. Hasil dari penelitian ini juga akan memberikan pengetahuan dan pemahaman kepada masyarakat atau pelaku bisnis agar lebih selektif memilih auditor untuk melakukan pemeriksaan terhadap laporan keuangannya.

Keywords : Profesionalisme, Etika Profesi, Materialitas, Auditor

\section{Pendahuluan}

Audit merupakan suatu proses sistematik untuk memperoleh dan mengevaluasi bukti secara objektif mengenai pernyataan tentang kegiatan dan kejadian ekonomi,dengan tujuan untuk menetapkan tingkat kesesuaian antara pernyataan-pernyataan tersebut dengan kriteria yang telah ditetapkan,serta penyampaian hasilhasilnya kepada pemakai yang berkepentingan.Pengetahuan auditing ini menjadikan orang berkompeten untuk menilai kewajaran pertanggungjawaban 
keuangan,sehingga memungkinkan orang terjun dalam profesi akuntan publik yang mampu menghasilkan jasa yang menjadikan investor dapat memperoleh informasi keuangan yang handal.Informasi keuangan yang handal dapat memberikan dasar yang handal untuk mengambil keputusan pengalokasian sumber daya ekonomi secara efektif dan efisien.

Dari uraian diatas, akuntan publik merupakan profesi sangat penting dan krusial untuk memegang teguh profesionalisme dan etika profesinya. Jika dua hal ini diabaikan, pemeriksaan/audit laporan keuangan perusahaan akan menghasilkan laporan yang tidak obyektif, penuh dengan kepentingan banyak pihak, sehingga opini atau hasil penilaian auditor menjadi tidak bisa dipercaya. Pihak-pihak yang sangat berkepentingan terhadap laporan akuntan publik/auditor ini adalah, pihak investor, pemerintah, kreditur dan masyarakat. Selama ini opini auditor digunakan sebagai pedoman bagi investor untuk menanamkan modalnya, pemerintah terkait dengan kepentingan pajak dan kebijakan moneter lainnya, kreditur memerlukan laporan ini sebagai dasar untuk pemberian kredit dan menilai kemampuannya untuk mengembalikan kredit. Akan terjadi krisis ekonomi yang luar biasa besar pada suatu negara jika laporan auditor/akuntan publik ini direkayasa maupun dimanipulasi. Maka dari itu profesionalismen dan penegakan etika profesi sangat penting terhadap profesi akuntan publik ini.

Selain menjadi seorang profesional yang harus memiliki sikap profesionalisme, akuntan publik juga harus memiliki pengetahuan yang memadai dalam profesinya dalam mendukung pekerjaannya melakukan setiap pemeriksaan. Setiap akuntan publik juga diharapkan memegang teguh etika profesi yang sudah ditetapkan oleh Institut Akuntan Publik Indonesia (IAPI), agar situasi penuh persaingan tidak sehat dapat dihindarkan. Selanjutnya, dalam perencanaan audit, akuntan publik harus mempertimbangkan masalah penetapan tingkat risiko pengendalian yang direncanakan dan pertimbangan awal tingkat materialitas untuk pencapaian tujuan audit.

Penelitian ini menjadi penting karena untuk mengetahui pengaruh profesionalisme auditor dan etika profesi dapat membantu auditor dalam mempertimbangkan tingkat materialitas sehingga dapat meningkatkan kualitas kinerja auditor dalam membuat keputusan mengenai kewajaran laporan keuangan dengan yang disajikan oleh klien, sehingga kepercayaan masyarakat terhadap jasa yang diberikan oleh auditor semakin meningkat.

Mengingat luasnya penelitian ini, maka penelitian ini dibatasi hanya padaKantor Akuntan Publik yang berada di kota Surabaya.Penelitian ini dilakukan dengan tujuan untuk memberikan bukti empiristentang pengaruh profesionalisme auditor dan etika profesi terhadap pertimbangan tingkat meterialitas untuk tujuan audit laporan keuangan.

\section{Landasan Teori}

\section{Audit Laporan Keuangan}

Menurut Agoes (2010) ada dua alasan laporan keuangan harus diaudit oleh Kantor Akuntan Publik (KAP), yaitu pertama, jika tidak diaudit ada kemungkinan bahwa laporan keuangan tersebut mengandung kesalahan baik yang disengaja maupun yang tidak 


$\begin{array}{lll}\text { disengaja sehingga diragukan } & \text { profesi yang memberikan jasa } \\ \text { kewajarannya oleh pihak-pihak } & \begin{array}{l}\text { pelayanan kepada masyarakat dan } \\ \text { merupakan alat kepercayaan bagi }\end{array} \\ \text { yang berkepentingan terhadap } & \begin{array}{l}\text { masyarakat luas. Dengan demikian } \\ \text { laporan keuangan. Kedua, jika }\end{array} \\ \text { laporan keuangan sudah diaudit dan } & \text { dapat disimpulkan bahwa setiap } \\ \text { mendapat opini wajar tanpa } & \text { profesional wajib mentaati etika } \\ \text { pengecualian (Unqualified Opinion) } & \text { profesinya terkait dengan pelayanan } \\ \text { dari KAP, berarti laporan keuangan } & \text { yang diberikan apabila menyangkut } \\ \text { tersebut dapat diasumsikan bebas } & \text { kepentingan masyarakat luas. }\end{array}$

dari salah saji material dan telah disajikan sesuai dengan Standar Akuntansi Keuangan (SAK) yang berlaku umum di Indonesia. dalam semua hal yang material. Di sinilah peran akuntan publik dalam menentukan tingkat materialitas dalam proses audit laporan keuangan.

\section{Profesionalisme Auditor}

Independensi sikap mental memiliki arti tidak mudah dipengaruhi, dan tidak memihak pada kepentingan siapapun. Dua kata kunci dalam pengertian independensi adalah : (1) objektivitas, yaitu suatu kondisi yang tidak bias, adil, dan tidak memihak, dan (2) integritas, yaitu prinsip moral yang tidak memihak, jujur, memandang dan mengemukakan fakta apa adanya (Iz Irene, 2010: 35 ). Independensi auditor dibedakan menjadi dua, yaitu independen dalam kenyataan (independence in fact) dan independen dalam penampilan (independence in appearance).

\section{Etika Profesi}

Dalam hal etika, sebuah profesi harus memiliki komitmen moral yang tinggi yang dituangkan dalam bentuk aturan khusus. Aturan ini merupakan aturan main dalam menjalankan atau mengemban profesi tersebut, yang biasa disebut sebagai kode etik. Kode etik harus dipenuhi dan ditaati oleh setiap

\section{Materialitas}

Materialitas merupakan salah satu konsep baik dalam audit maupun akuntansi yang penting dan mendasar. Konsep berarti rancangan, gagasan atau rencana tindakan yang konseptual. Dalam akuntansi, materialitas dihubungkan dengan ketepatan manajemen dalam mencatat dan mengungkapkan aktivitas perusahaan dalam laporan keuangan.

\section{Hipotesis}

Berdasarkan lima dimensi dari profesionalisme dan 1 dimensi dari etika profesi tersebut, maka hipotesis yang diajukan dalam penelitian ini adalah :

\section{Pengaruh Pengabdian Pada Profesi Terhadap Pertimbangan Tingkat Materialitas \\ Penelitian Fridati (2005)} telah menguji profesionalisme auditor mengenai kualitas audit yang ada. Pengabdian pada profesi dicerminkan dari dedikasi profesionalisme dengan menggunakan pengetahuan dan kecakapan yang dimiliki. Pekerjaan didefinisikan sebagai tujuan, bukan hanya sebagai alat untuk mencapai tujuan. Totalitas ini sudah menjadi komitmen pribadi, sehingga kompensasi utama yang di harapkan dari pekerjaan adalah kepuasan 
rohani, baru kemudian materi. Dengan totalitas yang dimiliki auditor akan lebih hati-hati dan bijaksana dalam menentukan tingkat materialitas. Berdasarkan pemikiran diatas, maka hipotesis sebagai berikut:

\section{$\mathbf{H}_{1}$ : Ada pengaruh profesionalisme pengabdian pada profesi terhadap tingkat materialitas.}

\section{Pengaruh Kewajiban Sosial Terhadap Pertimbangan Tingkat Materialitas}

Penelitian sebelumnya yang dilakukan oleh Hastuti (2003) menyatakan bahwa kewajiban sosial mempunyai hubungan yang positif terhadap tingkat materialitas. Kewajiban sosial adalah suatu pandangan tentang pentingnya peranan profesi serta manfaat yang diperoleh baik masyarakat maupun profesional karena adanya pekerjaan tersebut. Kesadaran auditor tentang peran profesinya di masyarakat akan menumbuhkan sikap mental untuk melakukan pekerjaan sebaik mungkin. Berdasarkan uraian diatas, maka hipotesis sebagai berikut:

$\mathbf{H}_{2}$ : Ada pengaruh profesionalisme kewajiban sosial terhadap tingkat materialitas.

\section{Pengaruh Kemandirian}

Terhadap Pertimbangan Tingkat Materialitas

Kemandirian dimaksudkan sebagai suatu pandangan seseorang yang profesional harus mampu membuat keputusan sendiri tanpa tekanan dari pihak lain (pemerintah, klien, mereka yang bukan anggota profesi) (Hall,
1968). Penelitian yang dilakukan oleh Fridati (2005) menyatakan bahwa kemandirian seorang auditor sangat diperlukan dalam menentukan tingkat materialitas. Pertimbangan-pertimbangan yang dibuat benar-benar berdasarkan pada kondisi dan keadaan yang dihadapi dalam proses pengauditan. Berdasarkan uraian diatas, maka hipotesis sebagai berikut:

$\mathbf{H}_{3}$ : Ada pengaruh profesionalisme kemandirian terhadap tingkat materialitas.

4. Pengaruh Keyakinan pada peraturan profesi Terhadap Pertimbangan Tingkat Materialitas

Keyakinan terhadap profesi adalah suatu keyakinan bahwa yang paling berwenang menilai pekerjaan profesional adalah rekan sesama profesi, bukan orang luar yang tidak mempunyai kompetensi dalam bidang ilmu dan pekerjaan auditor. Bila yang menilai pekerjaan mempunyai pengetahuan yang sama, maka kesalahan akan dapat diketahui. Penelitan yang dilakukan oleh Wahyudi (2006) menyatakan bahwa keyakinan terhadap profesi mempengaruhi tingkat materialitas. Berdasarkan uraian diatas, maka hipotesis sebagai berikut:
$\mathbf{H}_{4}$ : Ada pengaruh profesionalisme kepercayaan profesi terhadap tingkat materialitas.

\section{Pengaruh Hubungan Dengan Sesama Profesi Terhadap Pertimbangan Tingkat Materialitas.}




\begin{tabular}{|c|c|}
\hline \multicolumn{2}{|l|}{$\begin{array}{l}\text { Hubungan sesama profesi } \\
\text { lah menggunakan ikatan } \\
\text { fesi sebagai acuan, termasuk } \\
\text { lalamnya organisasi formal dan } \\
\text { ompok kolega informal sebagai } \\
\text { utama dalam pekerjaan. } \\
\text { lalui ikatan profesi ini para } \\
\text { fesional membangun kesadaran } \\
\text { fesional. Dengan banyaknya } \\
\text { abahan masukan akan } \\
\text { nambah akumulasi pengetahuan } \\
\text { litor sehingga dapat lebih } \\
\text { aksana dalam membuat } \\
\text { encanaan dan pertimbangan } \\
\text { am proses pengauditan } \\
\text { ahyudi (2006). Berdasarkan } \\
\text { ian diatas, maka hipotesis }\end{array}$} \\
\hline & \\
\hline
\end{tabular}

\section{Pengaruh Etika Profesi Terhadap Pertimbangan Tingkat Materialitas.}

Agoes (2004) menunjukkan kode etik IAPI dan aturan etika Kompartemen Akuntan Publik, Standar Profesi Akuntan Publik (SPAP) dan standar pengendalian mutu auditing merupakan acuan yang baik untuk mutu auditing. Prinsip-prinsip etika yang dirumuskan IAPI dan dianggap menjadi kode etik perilaku akuntan Indonesia (1) tanggung jawab, (2) kepentingan masyarakat, (3) integritas, (4) obyektifitas, (5) kompetensi dan kehati - hatian, (6) kerahasiaan, dan (7) perilaku profesional. Semakin tinggi akuntan publik menaati kode etik maka semakin baik pula pertimbangan tingkat materialitas. Tanpa etika, profesi akuntan tidak akan ada karena fungsi akuntan adalah sebagai penyedia informasi untuk proses pembuatan keputusan bisnis oleh para pelaku bisnis. Etika profesi merupakan karakteristik suatu profesi yang membedakan suatu profesi dengan profesi lain, yang berfungsi untuk mengatur tingkah laku para anggotanya (Murtanto dan Marini, 2003). Berdasarkan uraian tersebut, maka hipotesis yang diajukan sebagai berikut:

\section{$\mathbf{H}_{6}$ : Etika profesi berpengaruh secara positif terhadap pertimbangan tingkat materialitas dalam proses audit laporan keuangan.}

\section{Pengaruh Profesionalisme dan Etika Profesi Terhadap Pertimbangan Tingkat Materialitas}

Penelitian sebelumnya yang dilakukan oleh Wahyudi (2006) dan Fidati (2005) menyatakan bahwa profesionalisme auditor yang terdiri dari dedikasi terhadap profesi, kewajiban sosial, otonomi, keyakinan terhadap peraturan profesi, afiliasi dengan sesama rekan seprofesi, dan pendidikan dapat mempengaruhi tingkat materialitas, Sedangkan dalam penelitian ini menurut Hall (1968) profesionalisme yang terdiri dari lima dimensi yaitu pengabdian pada profesi, kewajiban sosial, kemandirian, keyakinan profesi, dan hubungan dengan rekan seprofesi dapat mempengaruhi tingkat materialitas. Dengan penambahan Tanpa etika, profesi akuntan tidak akan ada karena fungsi akuntan adalah sebagai penyedia informasi untuk proses pembuatan keputusan bisnis oleh 
para pelaku bisnis. Etika profesi merupakan karakteristik suatu profesi yang membedakan suatu profesi dengan profesi lain, yang berfungsi untuk mengatur tingkah laku para anggotanya (Murtanto dan Marini, 2003). Berdasarkan uraian penelitian diatas, maka hipotesis sebagai berikut:

$\mathrm{H}_{7}$ : Ada pengaruh Profesionalisme dan Etika Profesi terhadap pertimbangan tingkat materialitas.

\section{Metode}

Penelitian ini bersifat kuantitatif karena data penelitian ini akan diolah secara statistika dengan program SPSS serta bersifat correlation study yang bermaksud untuk mengetahui hubungan antara variabel independen, dalam hal ini profesionalisme auditor dan etika profesi dengan variabel dependen, berupa pertimbangan tingkat materialitas.

Untuk mengukur profesionalisme auditor, digunakan 5 dimensi profesionalisme auditor. Seorang auditor dikatakan profesional apabila auditor memiliki perilaku profesional sebagai cerminan dari sikap profesionalisme. Konsep profesionalisme yang dikembangkan bagi para eksternal auditor tersebut merupakan konsep yang dilihat dari level individual. Seorang eksternal auditor yang dianggap profesional harus memiliki : (1) pengabdian pada profesi, (2) kewajiban sosial, (3) kemandirian, (4) keyakinan pada profesi, (5) hubungan dengan sesama profesi.

\section{Kerangka penelitian}

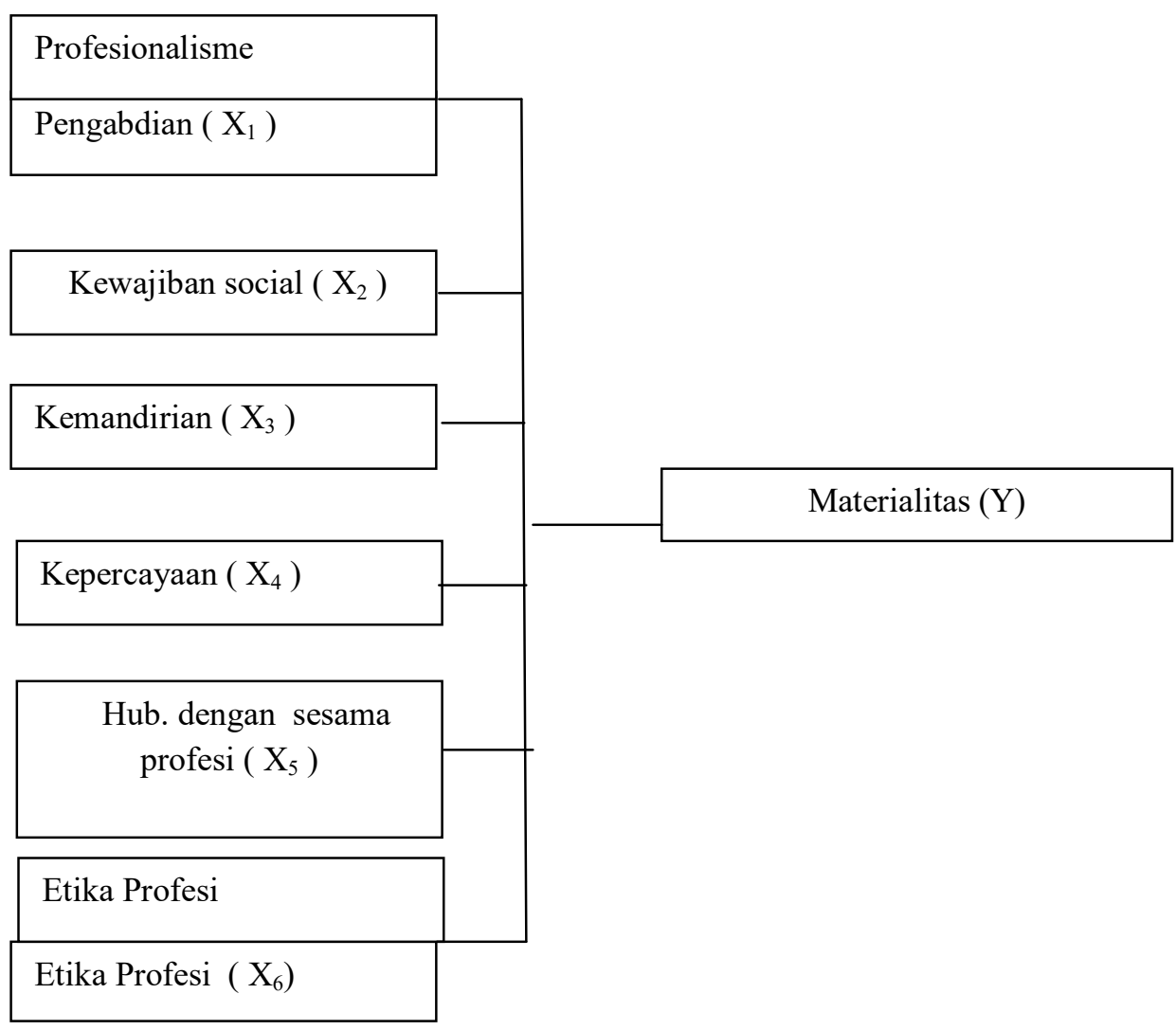




\section{Populasi dan Sampel Penelitian 1. Populasi}

Dalam penelitian ini populasi adalah keseluruhan auditor yang bekerja di Kantor Akuntan Publik (KAP) di Surabaya.Dalam penelitian ini yang menjadi populasi adalah seluruh auditor yang bekerja pada kantor akuntan publik di Surabaya sampai tahun 2009 kantor akuntan publik yang terdapat di IAPI sebanyak 43 KAP.

\section{Sampel}

Sampel penelitian ini diambil secara acak dengan dengan metode probability sampilng atau sering disebut juga dengan random sampling, yaitu tehnik pengambilan sampel yang memberikan peluang yang sama bagi setiap unsur (anggota) populasi untuk dipilih. Sugiyono (2008).
Dari KAP di Surabaya diperoleh 10 KAP. 10 KAP tersebut mempunyai beberapa pertimbangan:

a Termasuk KAP terbaik dan terbesar di Surabaya.

b KAP telah mengaudit perusahaan yang go publik atau perusahaan yang tercatat di Bursa Efek Indonesia.

c Termasuk KAP terbaik dan terbesar di Surabaya.

Sampel yang digunakan adalah karyawan magang, auditor junior, auditor senior, supervisor, manajer dan partner auditor yang bekerja pada tiap-tiap KAP tersebut. Tiap KAP diambil sebanyak 7 orang sampel. $10 \mathrm{KAP}$ yang digunakan dalam sampel penelitian ini adalah sebagai berikut:

Tabel Nama-nama Kantor Akuntan Publik

\begin{tabular}{|c|c|c|}
\hline No. & $\begin{array}{c}\text { Nama KAP } \\
\text { (Kantor Akuntan Publik) }\end{array}$ & Alamat KAP \\
\hline 1 & KAP. DRA.Dian Hajati D. & $\begin{array}{l}\text { Komplek Ruko Rungkut Megah Raya Blok Q - } 6 \\
\text { Surabaya } 60293\end{array}$ \\
\hline 2 & KAP. Agus \& Muratno (CAB) & $\begin{array}{l}\text { Komplek Deltasari Indah Blok BH - } 50 \text { Waru, } \\
\text { Sidoarjo }\end{array}$ \\
\hline 3 & $\begin{array}{l}\text { KAP. Aryanto Amir Jusuf \& } \\
\text { Mawar (CAB) }\end{array}$ & $\begin{array}{l}\text { J1. Mayjend. Sungkono Komplek Darmo Park } 1 \\
\text { Blok III B } 17 \text { Surabaya } 60256\end{array}$ \\
\hline 4 & KAP. Didy, Tjiptohadi \& Rekan & $\begin{array}{l}\text { Komplek Mangga Dua J1. Jagir Wonokromo No, } \\
100 \text { Surabaya } 60244\end{array}$ \\
\hline 5 & KAP. DRS. J.B. Waworuntu & $\begin{array}{l}\text { Regency Kuda Dua Blok A } 14 \text { Komplek Mangga } \\
\text { Dua Jl. Jagir Wonokromo No. } 100 \text { Surabaya } \\
60244\end{array}$ \\
\hline 6 & $\begin{array}{l}\text { KAP. DRS.J. Tanzil \& Rekan } \\
\text { (PUSAT) }\end{array}$ & $\begin{array}{l}\text { J1. Mayjend Sungkono, Darmo Park II Blok III } \\
\text { no. } 19-20 \text { Surabaya } 60227\end{array}$ \\
\hline
\end{tabular}




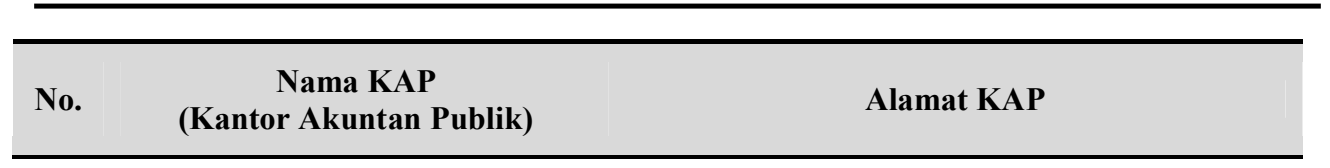

7 KAP. DRS. J.B. Waworuntu

Koko Perdana Building Lantai 2, R. $110 \mathrm{Jl}$.

8 KAP. Junaidi, Labib, Subyakto \& Rekan (CAB)

9 KAP. Osman Bing Satrio \& Rekan (CAB)

10 KAP. DRS. Widartoyo
Gedung Wika Lantai 3 Jl. A. Yani No.176 -178 Surabaya 60235

Gedung Bumi Mandiri 10 Floor Jl. Jend. Basuki Rachmat No. 129 - 137 Surabaya 60271

J1. Taman Kendangsari No. 7 Surabaya 60292

Sumber : IAI

\section{Instrumen Penelitian}

$\begin{array}{lrr}\text { Kuisioner } & \text { merupakan } \\ \text { pertanyaan yang } & \text { sudah }\end{array}$
diformulasikan secara tertulis untuk mendapatkan jawaban dari responden ( Indriantoro dan Supomo, 2001 ). Kuisioner dibuat berdasarkan penelitian sebelumnya. Kuisioner dalam penelitian ini memuat pertanyaan closed end dan opened end mengenai :

a. Identitas responden terdiri atas : (1) tanggal pengisian, (2) nama KAP, (3) nama responden (dapat tidak diisi), (4) jenis kelamin, (5) usia, (6) lama bekerja di Kantor Akuntan Publik, (7) kedudukan dalam Kantor Akuntan Publik, (8) latar belakang pendidikan akuntansi, (9) kursus-kursus dibidang akuntansi, keuangan dan pengauditan yang pernah diperoleh.

Pada butir keenam yaitu lamanya bekerja di Kantor Akuntan Publik responden depat memilih satu dari tiga pilihan : (1) kurang dari tiga tahun, (2) tiga sampai lima tahun, (3) lebih dari lima tahun. Pada butir ke tujuh, yaitu kedudukan dalam Kantor Akuntan Publik dibagi berdasarkan jenjang kedudukan mulai dari yang terendah sampai yang tertinggi ( karyawan magang, auditor junior, auditor senior, supervisor, manajer dan partner ). Latar belakang pendidikan berjenjang dari D3, S1, S2, S3 atau lain-lain. Pada pertanyaan terakhir rensponden dapat mengisi berdasarkan kursuskursus yang pernah diikuti sebagai tambahan pendidikan diluar pendidikan formal.

b. Sikap atau pendapat responden terhadap pernyataan tentang profesionalisme auditor dinyatakan dalam skala 1-5 mulai dari sangat tidak setuju sampai sangat setuju. Variabel tersebut diwakili oleh 24 pernyataan, Sikap atau pendapat responden terhadap pernyataan tentang etika profesi dinyatakan dalam skala 1-5 mulai dari sangat tidak setuju sampai sangat setuju. Variabel tersebut diwakili oleh 7 pernyataan sedangkan sikap atau pendapat auditor mengenai pertimbangan materialitas dinyatakan dalam skala 1-5 mulai dari sangat tidak setuju sampai dengan sangat setuju diwakili oleh 19 pernyataan. 
Hasil Penelitiaan dan Pembahasan

Deskripsi Responden

Deskripsikarakteristik

responden berdasarkan jenis kelamin berdasarkan output descriptive statistics dapat di ketahui bahwa sebagaianbesar(53,3\%) auditor di wilayah surabaya (reponden) berjenis kelamin Laki - laki, sedangan sisanyaperempuan $(46,7 \%)$. Usia berdasarkan output descriptive statistics dapat di ketahui bahwa responden sebagian besar $(53,3 \%)$ responden berusia antara $20-24$ tahun, yang berusia antara $25-29$ tahun sebesar $33,3 \%$, yang berusia antara 30 -34 tahun sebesar 10,0\% sedang sisanya (3\%) berusia antara35 - 40 tahun.Lama bekerja berdasarkan output descriptive statistics dapat di ketahui bahwa responden sebagian besar $(80 \%)$ respondenlama bekerja di KAP $<3$ tahun, yang bekerja selama 3 - 5 tahun sebesar 13,3\%, yang lama bekerja $>5$ tahun sebesar 6,7 \%.Kedudukan berdasarkan output descriptive statistics dapat di ketahui bahwa $30 \quad \%$ respondenberkedudukan sebagai karyawan magang, yang berkedudukan sebagai auditor junior sebesar $40 \%$, yang berkedudukan sebgai auditor senior sebesar $20 \%$ sedang sisanya (10\%) berkedudukan sebagai supervisior. Pendidikan berdasarkan output descriptive statistics dapat di ketahui bahwa 10 $\%$ respondenlulusan D3, reponden luusan S1 sebesar 87,6 \%, sedang sisanya 3,3 \% lulusan S2. Kursus berdasarkan tabel diatas dapat di ketahui bahwa sebagian besar responden tidak pernah mengikuti kursus tambahan pendidikan diluar pendidikan formal $80 \%$ sedang sisanya $20 \%$ pernah mengikuti kursus tambahan pendidikan dilar pendidikan formal .

\section{Uji Validitas dan Reliabilitas}

Variabel profesionalisme auditor diliat dari dimensi pengabdian terhadap profesi bernilaidiatas $\mathrm{r}$ tabel sehingga semua corrected itemtotal correlation yang nilai r-hitung $>$ r-tabel dinyatakan valid dimana hal ini diperoleh dari r-tabel 0,361. Kecuali untuk pertanyaan auditor terlibat secara emosional terhadap KAP dimana auditor bekerja kurang dari r-tabel maka ia dinyatakan tidak valid, dan dari tabel reliabelitas diperoleh alpha hitung sebesar 0,854 $>$ alpha tabel sehingga dapat disimpulkan bahwa variabel-variabel butir dinyatakan reliabel.

Variabel profesionalisme auditor diliat dari dimensi kewajiban sosialbernilai diatas $r$ - tabel sehingga semua corrected item-total correlation yang nilai r-hitung $>$ r-tabel dinyatakan valid dimana hal ini diperoleh dari r-tabel 0,361. dan dari tabel reliabelitas diperoleh alpha hitung sebesar $0,854>$ alpha tabel sehingga dapat disimpulkan bahwa variabel-variabel butir dinyatakan reliable

Variabel profesionalisme
auditor diliat dari dimensi kemandirian untuk pertanyaan X1.3.1 sampai X1.3.3 bernilai diatas $r$ - tabel sehingga semua corrected item-total correlation yang nilai r-hitung $>\mathrm{r}$ tabel dinyatakan valid dimana hal ini diperoleh dari r-tabel 0,361. dan dari tabel reliabelitas diperoleh alpha hitung sebesar 0,904> alpha tabel sehingga dapat disimpulkan bahwa variabel-variabel butir dinyatakan reliabel.

Variabel profesionaisme auditor diliat dari dimensi keyakinan terhadap profesi untuk pertanyaan bernilai diatas $r$ - tabel sehingga semua corrected item-total correlation yang nilai r-hitung $>$ r-tabel 
dinyatakan valid dimana hal ini diperoleh dari r-tabel 0,361 . dan dari tabel reliabelitas diperoleh alpha hitung sebesar 0,726> alpha tabel sehingga dapat disimpulkan bahwa variabel-variabel butir dinyatakan reliabel.

Variabel profesionalisme auditor diliat dari dimensi hubungan dengan sesama profesi bernilai diatas $r$ - tabel sehingga semua corrected item-total correlation yang nilai $r$ hitung $>$ r-tabel dinyatakan valid dimana hal ini diperoleh dari r-tabel 0,361. dan dari tabel reliabelitas diperoleh alpha hitung sebesar 0,779 $>$ alpha tabel sehingga dapat disimpulkan bahwa variabel-variabel butir dinyatakan reliabel. variabel etika profesi auditor diliat dari dimensi kompetensi dan kehati hatian untuk pertanyaan bernilai diatas $r$ - tabel sehingga semua corrected item-total correlation yang nilai r-hitung $>$ r-tabel dinyatakan valid dimana hal ini diperoleh dari rtabel 0,361. dan dari tabel reliabelitas diperoleh alpha hitung sebesar 0,925> alpha tabel sehingga dapat disimpulkan bahwa variabel-variabel butir dinyatakan reliabel.
Variabel etika profesi auditor diliat dari dimensi kerahasiaan untuk pertanyaan X2.2.1 sampai X2.2.7 bernilai diatas $r$ - tabel sehingga semua corrected item-total correlation yang nilai r-hitung $>$ r-tabel dinyatakan valid dimana hal ini diperoleh dari r-tabel 0,361. dan dari tabel reliabelitas diperoleh alpha hitung sebesar 0,942> alpha tabel sehingga dapat disimpulkan bahwa variabel-variabel butir dinyatakan reliabel.

Variabel dependen tingkat materialitas bernilai diatas $\mathrm{r}$ - tabel sehingga semua corrected item-total correlation yang nilai r-hitung $>\mathrm{r}$ tabel dinyatakan valid dimana hal ini diperoleh dari r-tabel 0,361. Kecuali pada pertanyaan materialitas menurut auditor bukan merupakan sesuatu yang harus dipermasalahkan (Y6) dan pada pertanyaan ketepatan dalam menentukan tingkat materialitas tidak ditentukan oleh profesional atau tidaknya seorang auditordan dari tabel reliabelitas diperoleh alpha hitung sebesar 0,951> alpha tabel sehingga dapat disimpulkan bahwa variabelvariabel butir dinyatakan reliabel.

\section{UJI HIPOTESIS}

\section{Uji Regresi Linier Berganda}

\begin{tabular}{|c|c|c|c|c|c|c|c|c|}
\hline & \multicolumn{8}{|c|}{ Coefficients $^{a}$} \\
\hline & \multirow{2}{*}{ Model } & \multicolumn{2}{|c|}{ Unstandardized Coefficients } & \multirow{2}{*}{$\begin{array}{c}\text { Standardized } \\
\text { Coefficients } \\
\text { Beta }\end{array}$} & \multirow{2}{*}{$\mathrm{T}$} & \multirow{2}{*}{ Sig. } & \multicolumn{2}{|c|}{ Collinearity Statistics } \\
\hline & & B & Std. Error & & & & Tolerance & VIF \\
\hline \multirow[t]{3}{*}{1} & (Constant) & 4.220 & 6.376 & & .662 & .514 & & \\
\hline & Total $\times 1$ & .536 & .150 & .634 & 3.562 & .001 & .234 & 4.266 \\
\hline & Total $\times 2$ & .389 & .244 & .284 & 1.597 & .122 & .234 & 4.266 \\
\hline
\end{tabular}




$$
\mathrm{Y}=4.220+0.536 \mathrm{X} 1+0.389 \mathrm{X} 2+\mathrm{e}
$$

Konstanta sebesar 4.220 dan bertanda positif menunjukkan adanya pertumbuhan variable Tingkat Materialitas (Y) jika variable Profesionalisme Auditor (X1),dan Etika Profesi (X2) tidak melakukan aktivitas sama sekali. Artinya bahwa jika tidak ada profesionalisme dan etika profesi maka tingkat materialitas naya sebesar 4220.

Variabel Profesionalise Auditor (X1) Berpengaruh Positif terhadap Tingkat Materialitas sebesar 0.536 yang menerangkan bila variable Profesionalisme Auditor meningkat 1 satuan maka nilai Tingkat Materialitas akan meningkat sebesar 0.536 satu satuan, jika variable Etika Profesi tetap.
Variabel Etika Profesi (X2) Berpengaruh positif terhadap Tingkat Materialitas sebesar 0.389 yang menerangkan bila variable Etika Profesi meningkat 1 satuan maka nilai Tingkat Materialitas akan meningkat sebesar 0.389 satu satuan, jika variable Profesionalisme Auditor tetap.

\section{Uji F}

Pada pengujian ini digunakan untuk mengukur pengaruh variabel bebas yang meliputi profesionalisme dan etika profesi secara bersama-sama berpengaruh terhadap variabel terikat yaitu tingkat materialitas. Adapun hasil perhitungan niali uji $F_{\text {hitung }}$ adalah sebagai berikut:

\begin{tabular}{llrrrrr}
\multicolumn{7}{c}{ ANOVA $^{\mathbf{b}}$} \\
\hline Model & & Sum of Squares & Df & Mean Square & F & Sig. \\
\hline 1 & Regression & 5033.902 & 2 & 2516.951 & 53.730 & $.000^{\mathrm{a}}$ \\
& Residual & 1264.798 & 27 & 46.844 & & \\
& Total & 6298.700 & 29 & & & \\
\hline
\end{tabular}

a. Predictors: (Constant), totalx2, totalx1

b. Dependent Variable: totaly

Nilai $F_{\text {Hitung }}(53,730)>F_{\text {Tabel }}$ $(3,34)$ maka variable Profesionalisme Auditor (X1), dan Etika Profesi (X2) secara bersama-sama berpengaruh terhadap Tingkat Materialitas (Y) pada taraf signifikansi $0,000000<$ $\alpha 0,05$ menyimpulkan bahwa profesionalisme dan etika profesisecara bersama-sama berpengaruh terhadap tingkat materialitas.

\section{Uji T}

Pada pengujian ini digunakan untuk mengukur pengaruh variable bebas yang meliputi produkprofesionalisme dan etika profesi secara parsial terhadap variabel terikat yaitu variabel tingkat materialitas. 


\begin{tabular}{|c|c|c|c|c|c|c|c|c|}
\hline \multicolumn{9}{|c|}{ Coefficients $^{a}$} \\
\hline & \multirow{2}{*}{ Model } & \multirow{2}{*}{$\begin{array}{c}\text { Unstandardized } \\
\text { B }\end{array}$} & \multirow{2}{*}{$\begin{array}{l}\text { Coefficients } \\
\text { Std. Error }\end{array}$} & \multirow{2}{*}{$\begin{array}{c}\text { Standardized } \\
\text { Coefficients } \\
\text { Beta }\end{array}$} & \multirow{2}{*}{$\mathrm{T}$} & \multirow{2}{*}{ Sig. } & \multicolumn{2}{|c|}{ Collinearity Statistics } \\
\hline & & & & & & & Tolerance & VIF \\
\hline \multirow[t]{3}{*}{1} & (Constant) & 4.220 & 6.376 & & .662 & .514 & & \\
\hline & Total x1 & .536 & .150 & .634 & 3.562 & .001 & .234 & 4.266 \\
\hline & Total $\times 2$ & .389 & .244 & .284 & 1.597 & .122 & .234 & 4.266 \\
\hline
\end{tabular}

a. Dependent Variable : totaly

$$
\text { Nilai } T_{\text {Hitung }}(3,562)>T_{\text {Tabol }}
$$
$(1,701)$, maka profesionalisme auditor secara individu mempunyai pengaruh positif terhadap tingkat materialitas dengan taraf signifikansi $0,001<\alpha 0,05$, maka hal ini menunjukkan bahwa secara parsial variabel profesionalisme berpengaruh secara signifikan terhadap tingkat materialitas.
Nilai $T_{\text {Hitung }}(1,597)<T_{\text {Tabol }}$ $(1,701)$, maka etika profesi secara individu kurang mempunyai pengaruh terhadap tingkat materialitas dengan taraf signifikansi $0,122>\alpha 0,05$, maka hal ini menunjukkan bahwa secara parsial variabel etika profesi berpengaruh secara signifikan terhadap tingkat materialitas

\section{Koefisien Regresi}

\begin{tabular}{|c|c|c|c|c|c|c|c|c|c|c|}
\hline \multirow[b]{2}{*}{ Model } & \multirow[b]{2}{*}{$\mathrm{R}$} & \multirow[b]{2}{*}{ R Square } & \multirow{2}{*}{$\begin{array}{l}\text { Adjusted R } \\
\text { Square }\end{array}$} & \multirow{2}{*}{$\begin{array}{l}\text { Std. Error of } \\
\text { the Estimate }\end{array}$} & \multicolumn{4}{|c|}{ Change Statistics } & \multirow[b]{2}{*}{$\begin{array}{c}\text { Sig. F } \\
\text { Change }\end{array}$} & \multirow[b]{2}{*}{$\begin{array}{l}\text { Durbin- } \\
\text { Watson }\end{array}$} \\
\hline & & & & & $\begin{array}{c}\text { R Square } \\
\text { Change }\end{array}$ & F Change & df1 & $\mathrm{df} 2$ & & \\
\hline 1 & $.894^{a}$ & .799 & .784 & 6.844 & .799 & 53.730 & 2 & 27 & .000 & 2.249 \\
\hline
\end{tabular}

Nilai R Square dari hasil perhitungan sebesar 0.799 atau $79,9 \%$ yang berarti bahwa variable terikat yakni Tingkat Materialitas (Y) hanya sebesar $79,9 \%$ dapat di jelaskan oleh variable bebas Profesionalisme Auditor (X1), Etika Profesi (X2), dan sisanya 20,1\% dijelaskan oleh variable yang tidak dimasukkan dalam model.

\section{SIMPULAN DAN SARAN \\ Simpulan}

Profesionalisme auditor secara individu mempunyai pengaruh positif terhadap tingkat materialitas dengan taraf signifikansi $0,001<0,05$. Nilai
$T_{\text {Hitung }}(1,597)<T_{\text {Tasml }}(1,701)$, maka etika profesi secara individu mempunyai pengaruh negative terhadaptingkat materialitas dengan taraf signifikansi $0,122>0,05$

\section{Saran}

Untuk penelitian yang akan datang di harapkan untuk mencari faktor-faktor yang mendominasi untuk mempengaruhi Profesionalisme Auditor dan Etika Profesi terhadap Pertimbangan Tingkat Materialitas

\section{Keterbatasan Penelitan}

Lingkup penelitian ini hanya wilayah Surabaya dan blum 
mencakup Kantor akuntan publik yang memiliki nama bertaraf internasional sehingga data yang diperoleh kurang dapat menggambarkan keadaan auditor yang sebenarnya di Indonesia.

\section{DAFTAR PUSTAKA}

Agoes, S. 2004. Auditing, Pemeriksaan Akuntan oleh Kantor Akuntan Publik. Jakarta: LPFE-UI.

Agoes, S. dan I Cenik Ardana. Etika

Bisnis dan Profesi

Tantangan Membangun Manusia Seutuhnya. Jakarta. Penerbit Salemba Empat.

Arens, A.A., RJ. Elder, M.S. Beasley. 2005. Auditing and Assurance Services, an Intergrated Approach, Prentice Hall, Pearson.

Fridanti, Winda. 2005. Analisis Hubungan Antara Profesionalisme Auditor Dengan Pertimbangan Tingkat Materialitas Dalam Proses Pengauditan Laporan keuangan di Yogyakarta. Program Sarjana UII Yogyakarta. Yogyakarta.

Hall, $\quad$ Richard, 1968. "Professionalism a Bureaucratization", Americ Sosiological Review, 33: 92-104.

Ikatan Akuntan Indonesia. 2001. Standar Profesional Akuntan Publik. Salemba Empat.Jakarta.
Indriantoro \& Supomo. 2001. Metodologi Penelitian Bisnis. Cetakan Pertama, BPFE Yogyakarta.

Mulyadi. 2002. Buku Satu, Edisi Enam. Salemba Empat, Jakarta.

Murtanto dan Marini. 2003. Persepsi Akuntan Pria dan Akuntan Wanita serta Mahasiswa dan Mahasiswi Akuntansi terhadap Etika Bisnis dan Etika Profesi Akuntan, Proseding Simposium Nasional Akuntansi VI, Oktober,

Sugiyono, Prof, DR. 2008. Metode Penelitian Bisnis. Penerbit Alfabeta, Bandung.

Syahrir. 2002. Analisis Hubungan Antara Profesionalisme Akuntan Publik Dengan Kinerja, Kepuasan Kerja, Komitmen, dan Keinginan Berpindah. Program Pascasarjana UGM. Yogyakarta.

Wahyudi dan Mardiyah. 2006. Pengaruh Profesionalisme Auditor terhadap Tingkat Materialitas Dalam Pemeriksaan laporan Keuangan. Program Pascasarjana UNIBRAW Malang.

Yustrida Bernawati. 1994. Faktorfaktor Yang Dipertimbangkan Akuntansi Dalam Penentuan Materialitas. Program Sarjana UGM. Yogyakarta. 